Yulija Orlovs'ka,

Doctor of Economics, Professor, Head of the Department of International Economics SHEI "Prydnyprovsk State Academy of Civil Engineering and Architecture" (Dnipro, Ukraine);

Olesia Kvaktun,

Candidate of Economic Sciences, Associated Professor, Associated Professor of the Department of International Economics SHEI "Prydnyprovsk State Academy of Civil Engineering and Architecture" (Dnipro, Ukraine);

Veronika Chala,

Candidate of Economic Sciences, Associated Professor of the Department of International Economics, SHEI "Prydnyprovsk State Academy of Civil Engineering and Architecture" (Dnipro, Ukraine);

Marta Vovk,

Candidate of Economic Sciences, Associated Professor of the Department of International Economics, SHEI "Prydnyprovsk State Academy of Civil Engineering and Architecture" (Dnipro, Ukraine)

\title{
GREEN INVESTMENTS' PROGRAMS AS AN ELEMENT OF INDUSTRY'S INTERNATIONAL COMPETITIVENESS (ON EXAMPLE OF CONSTRUCTION INDUSTRY)
}

The definition of industry competitiveness was analyzed in the article. Authors insist on the fact that any industry's success does not depend only on inherited factors, but also on particular mechanisms which can enable constant effective application of these factors. In case of construction industry, the program of green investments is argued to be that specific international competitiveness' boosting mechanism. Thus, the principal program for green investments implementation in the regions of Ukraine is presented in order to increase international competitiveness of country construction industry. The main economic and social effects of "green technologies" in building industry are critically analyzed by authors.

Keywords: construction industry, international competitiveness, green investments, green technologies, green building, economic policy of green investments, sustainability of region.

DOI: 10.21272/mmi.2017.3-34

The articulation of the problem in general sense and its connection with important scientific or practical tasks. The sustainable provision of the international competitiveness at different levels (goods, enterprise, sector, region and country) remains one of the most difficult tasks in the world economy. Its solution in Ukraine, its regions and sectors of economy is complicated by the fact that the national experience in this area is insufficient. Thus, the task of ensuring the competitiveness of Ukrainian construction companies in the late XX century was relevant only for export-oriented individual firms, and only after radical economic reforms, the research of the competitiveness in this sector has acquired the theoretical and practical significance in Ukrainian science.

The international competitiveness is the most important comprehensive characteristic of the qualitative state of goods, enterprises, sectors, regions or a country, compared to relevant counterparts of other countries. New conditions of expanding competition, material and financial resources deficit generate a need for qualitative breakthroughs in the competitiveness and outperforming the competitors in the global market.

In up-to-date provision of the competitiveness of the sectors at the international market the important role is given to benefits of its resources-saving «green» technologies and materials, particularly in construction sector as the promising industry of the Ukrainian economy. In addition, media more and more provides society with information about construction projects that are implemented using the technologies of "green construction», in accordance with international systems of evaluation of the ecological compatibility as to real estate units. All this indicates that the issue of active development of 
the green construction and investments into it are rather relevant for Ukraine.

Analysis of recent researches and publications, in which the start to solve this problem is triggered and which the authors relied upon. The significant contribution to the study of problems of the international competitiveness at different levels is made by such foreign and domestic scientists as L. Antonyuk [5], V. Dergachova [11], J. Dunning[28], G. Hamel [29], N. Kalyuzhnova [13], D. Luk'yanenko [15], R. Narula [28], L. Piddubna [19], M. Porter [20, 21], A. Poruchnik [15], C. Prahalad [29], O. Shnipko [26] and others.

The problematics of green (ecological) investments and their classification is thoroughly considered in the works of domestic and foreign scientists, in particular of N. Andreieva [1], V. Anischenko [3] (ecological investments), C. Arestov [4] (environmental investments and investments to eco-social services), V. Blahyi [6] (green investments), V. Vlasov [9] (investments to rational natural management), 0 . Vyshnytska [8] (eco-investments) and others.

Highlighting earlier unsolved issues being a part of the general problem, to which the article is devoted. However, despite the full range of researches with regard to the international competitiveness at different levels of the management, problems and perspectives of the construction sector development in Ukraine and green investment, in particular, a program or a plan to increase the international competitiveness of the construction sector in Ukraine, considering the current global ecotrends, has not been developed so far.

Wording of the article purpose (setting of the task). The purpose of this article is to form a program of green investments in order to increase the international competitiveness of the construction sector in Ukrainian regions.

Presentation of the research basic material with full justification of the obtained scientific results. The concept of the competitiveness appeared, firstly, for the national economy and was connected with effectiveness of the country's participation in the international trade. This approach originates in the researches of the political economics classicists, who advanced theoretical provisions about the advantages of countries in the external trade, the implementation of which brings countries, participating in the international exchange, mutual benefits. Later all the theory of the international competition was focused on deepening these starting points. Gradually a broader approach to the concept of the competitiveness began to take shape in relation to goods, firm, sector and region. As a whole the competitiveness became considered as the indicator integrating three components: pricing, technological and structural ones.

The category of the competitiveness obtained the further development in early 90th years in the framework of "Technology and Economy" OECD program [31, p. 157], due to which the main factors of the national competitiveness were recognized as technology, innovative systems, as well as the general institutional and social environment along with the strategy of corporations and the efficient use of human capital, and also costs and prices, although their role was gradually reduced.

With regard to the competitiveness of the sector the researches are, as a rule, based on the determination of M. Porter [21]: «We determined the sector of the particular country as the successfully functioning one on an international scale in such case, when it had competitive advantages in comparison with the most competitive areas of the world market... We chose, as the most optimal parameters, the availability of substantial and stable export to a sufficiently large number of countries and / or the considerable export of investments based on the experience and assets created in this country». Features of this definition lie in the selection of the competitiveness criteria, under which it is possible to determine the level of the competitiveness in the sector within the system of the global economy.

Porter notes that the competitiveness of industries is based on competitive advantages, the whole diversity of which can be reduced to two basic types: 1) resource; 2) technology. Although, the competitiveness starts from resource factors and depends on: geographical location: climatic conditions; 
availability of natural resources in the country; skilled labor force; accumulated capital, the success in the international competition is determined not only by the production factors properly, but also, where and how efficiently they are used. Thus, these factors are not enough to keep success in the competitive struggle. The success in any field can be achieved not only due to the inherited factors, but also due to mechanisms capable to continuously improve the efficiency of using these factors.

Nowadays, the contribution of productive resources to increasing competitive advantages of commodity producers and a country is defined by their reserves, volumes, value, availability, as well as their structure, quality and efficiency of the use, speed of their creation, improvement and adaptation to needs of the national and global economy. The role of resource-saving technologies in ensuring the international competitiveness is enhanced, since there is observed the trend of diminishing energy-, capital-, and materials-intensity of products in the world economy under conditions of reduction of nonrenewable natural resources stocks. The majority of the industrialized countries actively use the resource-saving technologies (including, construction sphere) in contrast to mostly resource-intensive technologies in Ukraine, which reduce the competitiveness of Ukrainian enterprises at world markets.

The reason preventing the rapid decision-making in the construction sector is the lack of appropriate legislation, corruption, and unarranged informational activities as to scientific and technical proposals at the domestic level. These and other problems hinder the progress in development of such innovative line as green construction or eco-construction. The studies based on the assumption that the cost of ecological construction exceeds by $30 \%$ the cost of traditional construction indicate that the operating costs for the maintenance of a normal house are twice higher than for ecological one; moreover, they tend to the annual increase due to inflation. Assumptions about the possibility to sell $30-50 \%$ of energy surplus of the own generating equipment, used by the ecological building; reduce its operating costs even more. In addition, the total discounted costs for construction and operation of conventional and ecological buildings become equal over 25 years, which makes it possible to assert the feasibility of large initial investments to ecological construction [14].

In our article, based on previous studies of the authors $[17,18]$ we propose to improve the international competitiveness in the construction sector using green investments programs for the construction field exactly at the regional level. The reason is that the region is the certain territorial optimum, or is the set of the most favorable socio-economic and natural conditions on the certain territory, which, in case of proper organization, would give opportunity for the most efficient use of natural and labor resources, as well as the productive and social infrastructure [10].

It should be noted that the program must be designed for urban and rural areas separately, according to the level of calculated figures for sustainable territorial development [17]: genuine regional savings (GRS) and the integral index of sustainable development (IISD). According to these figures there are separated the territories of relatively higher sustainability (THS) and those of relatively lower sustainability (TLS). Since exactly the green construction and involvement of green investments affect the figures of sustainability in development and vice versa.

Measures of green investments were planned in such a way, that their implementation in urban and rural areas would lead to forecasted increase of those figures-elements for the genuine regional savings, which positively affect their integral value. And conversely, the program planned measures that reduce the GRS figures-elements, negatively affect the genuine regional savings as the integral figure of the sustainable development potential in the region. Let us consider the proposed principle measures in more details and in relation to relevant GRS figures.

The measures of green investments that increase the genuine regional savings can be deemed the following ones.

Volume of investments to modernization and reconstruction (IMR) is, obviously, a key figure, for the whole developed system of measures. But it is important to note that their «onter-groups» distribution 
was planned so as to increase volumes of investments to territories with relatively lower level of the sustainable development (TLS), compared to the group of territories of its relatively higher level (THS).

Volumes of investments into innovations $(\operatorname{lnl})$, as well as scientific developments and education have to be increased by the following measures:

1. The development of ecology-oriented and energy-efficient technologies of reconstruction in housing and utilities sector and construction of new housing, as well as new innovative and ecological construction. This area can be realized due to a) development of «bioclimatic» architecture, including the use of solar radiation in thermal balance of a building; b) «green» construction and reconstruction; c) designing «energy-passive» buildings, etc. [16]. It is planned for use in small and medium towns for the group of territories of the relatively lower sustainable development.

2. Innovations in paper production (they are also urgent to reduce consumption of the durable wood, that is why they increase possibility of nature «to process» $\mathrm{CO}_{2}$ - the component of losses from $\mathrm{CO}_{2}$ emissions will be reduced). As we can see, this measure has the double effect on the level of the genuine regional savings. Possible ways to implement are [7]: a) the use of secondary raw materials (energy consumption in paper production then reduces by $60 \%$ ); b) reconstruction of enterprises (construction of new ones) for production of hemp paper (not wood one); c) modernization of existing enterprises for paper production using soft low-cost wood species (reduction of energy consumption by $10 \%$ ). They are proposed for groups of regions with relatively lower sustainable development and lumber factories (rural areas).

3. Innovations in the field of building materials, such as production of the new generation of dry mixtures, which not only do not create additional emissions, but also are capable to «connect» $\mathrm{CO}_{2}$. As an example, we can cite the development of the cement by British Company "Novacem", where each ton absorbs 0,6 tons of $\mathrm{CO}_{2}$, while each ton of the standard cement «is in debt» for the emission of 0,4 tons of $\mathrm{CO}_{2}[30]$.

Measures reducing losses from irrational nature management (GRS annuity component), can be the following ones.

1. New construction of facilities for environmentally safe energy production, including the use of renewable energy sources and secondary raw materials, as well as reduction of energy losses during transportation, including through decentralization of energy production and energy supply of small consumers. It can be realized through: a) creation (expansion) of facilities for production of new generation solar energy; b) design and construction of residential and public buildings with maximum use of solar energy; c) purchase of equipment for accumulation of solar energy (with possibility to launch power exchanges so as it occurs in the power plant of Zurich [7]); d) construction of wind power generator installations. It is urgent for implementation for the group of territories of relatively lower sustainable development level, including, in rural areas within the framework of developing the private housing sector.

2. Capital investments in the field of waste management with the view to their involvement into the economic turnover. According to scientists [7], the former USSR utilized not more than $28 \%$ of waste of different origin. At the same time there is evidence as to the real use of only $5 \%$ of waste, the bulk of which is the metallurgical slag. Waste costs reach $10 \%$ of the product price (electric power, cast-iron, etc). The use of industrial waste allows covering up to $40 \%$ of construction needs in raw materials, reducing costs for manufacturing building materials by $10-30 \%$ and lowering the burden on the environment. However, today in the developed countries the industry of waste collection and recycling becomes one of the modern eco-business trends.

3. Reconstruction of existing facilities for power generation can occur due to such measures of green investments as [12]: a) reconstruction of generating units (for example, use of combined-cycle plants) and electric networks, which allow to reduce energy costs by $10-15 \%$; b) reconstruction of industrial 
steam plants, and compressor stations to increase the integrated energy efficiency output in combined energy generation (10\%-reconstruction reduces the energy consumption in the industry by up to $5 \%$ per 1 person); c) reconstruction, repairment and improvement of services for in-plant energy networks (in this case, energy savings can reach $20-30 \%$ ).

4. Considerable savings of non-renewable types of energy resources should be also caused by ecological reconstruction and modernization of main gas-forming sectors and industries. For example, in old industrial mining and metallurgical regions it is possible to have available: a) construction of technical units for cokeless and blast furnace-less metallurgy (energy consumption reduces to $15 \%$ per 1 ton of mill products); construction of facilities for disposal of all types of secondary energy resources, produced in iron and steel plants (energy consumption reduces to $15 \%$ per 1 ton of mill products) [25]. The last two components that reduce the general level of genuine regional savings are the damage from air pollution by $\mathrm{CO}_{2}$ emissions and losses from the diseases due to environmental contamination. It is obvious that measures of green investments should be aimed at reduction of these negative phenomena.

Reduction of $\mathrm{CO}_{2}$ emissions into the atmosphere, or even «binding» of their already existing volumes can be supported by the following main measures of green investments.

1. Development of the system of forest management investment mechanisms, which make profitable the improvement of ecological characteristics of forest ecosystems. These mechanisms can be realized through the following measures: a) capital investments to green planting on (in) buildings; b) «renewal» of forests due to greater use of tax and financial instruments (special local taxes; "green» mortgages, etc.); c) optimization of consumption and reforestation (to use wooden buildings more widely, and in this case, to actively renovate forests with new plantings - because exactly young forests «take» $\mathrm{CO}_{2}$ from the atmosphere) [7].

2. Adherence to the concept of the balanced proportionality in development of the territory between the areas of building-ups, forest areas, arable areas and the rest of the area (1:9:9:21), or the ratio (40:60 between the built-up area and another one on the territory [24]). Realization of such program purposes will be promoted by capital investment measures aimed at compliance with: a) ecologically sound forest cover (more than 25-30\% of the area) [24, p. 48]; b) building concepts of «hollowing» and «rising up» (instead of current trend of expanding building-up areas); c) areas of special protective territories (recommended by the International Union for Conservation of Nature - at least $10 \%$ of the total area [24, p. 49].

3. Creation of specific territorial system of the sustainable designing and construction of buildings and structures. The weighty effect of all the forms and methods of «green» designing and construction is the substantial reduction of $\mathrm{CO}_{2}$ emissions as well as their active absorption. For example, green roofs of buildings grown up on the basis of specific vegetation using modern methods of «sustainable» design gained popularity worldwide.

4. The «sustainable» development of underground space, which is implemented owing to [24]: a) design standards of wide range of underground buildings and structures; b) programs of transferring buildings and structures under the ground, primarily, in urban centers; c) programs of transferring railways under the ground with reproduction on their current locations of radical "green corridors» that connect all green areas and natural landscapes together to create opportunities of free migration of animals without crossing their paths with roads and buildings, as well as ensuring the possibility of hiking for people; d) programs of transferring highways under the ground with projects of «trapping» vehicle emissions, their collection and disposal under the ground, as well as purification of polluted air through its intake from transport tunnels.

Green investments that create conditions for reduction of morbidity arisen due to ecological reasons, can be presented by the following basic measures. 
1. Reduction of technogenic pressure through a technological upgrading of productions with outdated equipment and decrease in consumption of energy and resources, especially in construction sector. Possibilities of real ecological investments are there the following [7, 12]: a) outfit of enterprises with modern environmental equipment; b) use of isolating materials and structures (reduction of heat energy expenditure by $15 \%$ ); c) designs of buildings and energy-saving materials and structures (energy savings by $10 \%$ ); d) use of autonomous heating units instead of central heating stations (energy savings by more than $10 \%$ ); e) reduction in cement consumption (new structural solutions in monolithic reinforced concrete constructions; introduction of high-quality cement and waste: CHP ash, slag, etc.) (cost saving of cement by $20 \%$ per 1 person).

2. Healthy master layouts of cities and "green» technologies of designing. It is possible to realize owing to: a) urban building-up measures of incentive (motivation) for foot traffic - «city for bicycles and pedestrians», preferential parking for cars with electric or mixed engines; b) implementation of miniaturization provisions, «ecology video»; c) compliance with principles of sustainable design of buildings and engineering structures: designing with maximal preservation of soil-planting layer, with penetrating coatings, with use of underground space and rough terrains; d) design of buildings with passive use of solar energy, use of energy-saving space planning and structural solutions, equipment for full utilization of internal heat of buildings; e) introduction of automatic reaction systems for separate elements of buildings; for example, automatic opening / closing of windows, blinds, etc.); f) admissible use of ecological waste for manufacturing buildings elements; g) deconstruction, i.e. reuse of materials. To date in construction projects the share of reused materials amounts, unfortunately, only to $1 \%$; h) use of local materials providing close distance for transportation, that is fuel savings lead to reduction of $\mathrm{CO}_{2}$ emissions to the atmosphere from transport.

3. Provision of ecological labor and living safety. Buildings and structures must not be «rejected» by ecosystems, destroy (pollute) the environment, be an obstacle to the flow of connections and energy, give off pollution that is not subject to processing by the environment (for example, table slate, cinder blocks (radiation). Measures of implementation can be the following [24]: a) bio-adaptive buildings (buildings that are adapted to the existence of the wildlife on the surface and inside of buildings); b) rejection of non-renewable resources when "manufacturing» a building; c) preservation and restoration of eco-networks and recording migration channels in designing and construction. In the collective work [22, p. 134] it is emphasized that the idea of eco-network is one of the most productive and innovative in the modern ecology at the threshold of the third millennium.

4. The "green» tourism and ecological recreational facilities. It is possible to realize by such measures as: a) ecological reconstruction of the local land, borderland and recreational areas of industrial junctions and villages in order to create on this basis an attractive environment for living; b) ecological projects of "green» buildings for rest and treatment; c) increasing forest plantings (including by deductions from the cost of vouchers [24, p.54]).

5. Implementation of systems of ecological standards in designing and construction. For private customers the certification can be carried out voluntarily, for state ones - compulsorily. The principle for issuance of a certificate according to international standards is point-rating [24, p.68]. Existing projects are evaluated under two groups of figures (in two categories): environmental compatibility and vital capacity. Each aspect (figure) obtains points. The usual rating procedure follows further. After completion of construction it is necessary to confirm the project level of environmental compatibility, and only after this the procedure of certification is considered as completed.

Standards provide the "common language» for different countries; investors and banks make investments more easily to such projects, since they are sure that this is a "reasonable and effective» construction. It should be noted that the certification according to international «green» standards becomes the significant competitive advantage, increasing the profitability of the project, including owing 
Ю.В. Орловська, О.О. Квактун, В.С. Чала, М.С. Вовк. Програми зелених інвестицій як елемент міжнародної конкурентоспроможності галузі (на прикладі будівництва)

to the raised rental payment and reduction of operating costs (appreciated by potential investors).

In general, according to evaluations of scientists and columnists $[2 ; 7 ; 12 ; 23 ; 24 ; 25 ; 27 ; 30 ; 32]$ effects of «green technologies» in construction and designing are the following:

- Firstly, saving of 100 USD per square meter in connection to networks (due to the fact that request for facilities will be considerably less). In relative terms these are savings for: electric power costs - $43 \%$; heat costs - by $47 \%$; water costs - by $45 \%$.

- Secondly, reduction of energy needs for residential buildings by $25 \%$ (and since, for example, in USA residential buildings consume about $50 \%$ of all the energy, the effect is about $12,5 \%$ of all the energy consumed).

- Thirdly, the use of ecologically clean technologies for standardization of a building according to international standards_(LEED), which leads to increasing the cost of projects. Application of international standards (LEED) leads to increasing the cost of most «green» buildings approximately by $4 \%$, and the additional cost value can be amortized during the operation of a building and is usually compensated within 3-5 years through reduction of operating costs. It should be noted that in foreign projects there is an increase of investor's expenses by $3-12 \%$, while in foreign projects the integral investments are by $9 \%$ lower, than in standard project.

- Fourthly, the increase of the net operating income (3\% of the premium at the average rate of leasing contract) and decrease in quantity of refusals of rental property.

- Fifthly, the increase of the value of property assets_(for example, $10 \%$ of the premium for commercial values) leads, as a result, to reduction of financial and insurance costs.

- Sixthly, growing of the market of «green» building materials, on annual basis, from USD 455 billion in 2008 to USD 571 billion in 2013.

Based on the above-mentioned, we have developed the program of measures of green investments to construction sector of Ukrainian regions, which is divided into urban measures and those of rural areas under sustainability levels.

I. Cities (large - mainly for THS, medium and small - mostly for TLS) + municipal transportation:

a) relatively higher sustainability, THS: creation (expansion) of facilities for production of new generation solar energy; design of residential and public buildings using solar energy; planning of investment costs for certification according to «green» standards; ecological reconstruction of the local land, borderland and recreational areas of industrial junctions (examples of London and Freiburg); green plantings on (in) buildings; development of projects for reuse of building materials and structures; sustainable design of the «refusal» of non-renewable resources when «manufacturing» a building; reconstruction of existing facilities for energy production; ecological reconstruction and modernization of main gas-forming sectors and industries (blast furnace-less metallurgy, utilization of secondary energy resources, etc.); designing and construction of «reasonable» buildings, including bio-positive active ones 22a) regional center - for residents and visitors and not for cars»: the concept of «short roads» city; increasing the density of buildingup to the level of traditional European cities («reverse building-up»); creation of single network for different types of transport and expansion of passenger transport routes; capital investments to creation of centers for ecological standardization and certification of structures (of BREEAM and LEED types); providing buildings and structures with active bio-positive qualities (air and water purification through external surfaces); application in structures (primarily, for external surfaces) of only natural materials and nature-like substrate; withdrawal of a small part of the quarter territory for fruit and vegetable gardens, where compost and humus from residential houses come in design of buildings with the system of distribution of hard domestic waste; «sustainable» development of underground space;

b) relatively lower sustainability, TLS: construction of residential buildings using solar energy; design of «energy-passive» buildings; development of «bio-climatic» architecture, including the use of solar radiation in thermal balance of a building; bio-adaptive buildings (buildings that are adapted to existence of the 
wildlife on the surface and inside of buildings); preservation and restoration of eco-networks and recording of migration channels in designing and construction; new concepts of small towns - «eco-city» (low ergonomically-shaped buildings; ecological transport; mini-Combined Heat and Power Plants and solar energy); reconstruction, repair and improvement of servicing in-plant energy networks; acquisition (and, particularly, designing) of «ecological» and technologically advanced construction machinery; designing and construction of «green» buildings, including bio-positive passive ones; dsigning and construction of «sustainable development poles» - satellites of big cities (like «Uralska sloboda», "Greenwich Millennium», etc.); construction of over- and sub-surface buildings and structures with release of soil-planting layer; greening of all surfaces with fitting by special fasteners; creation of new facilities for production of local building «sustainable» materials (non-aggressive, suitable for recycling and reuse); design of ecological and architecturally expressive local landfills, which are closed by soil layer with greening; design of buildings with the system of distribution of the hard domestic waste; modernization: assemblage of systems for collecting water from solid surfacing, preservation and reuse; modernization: assemblage of systems for autonomous collection and purification of sewage; expanded implementation of low-rise and high density building-up («buildings are not higher than trees » - 6-7 floors).

II. Rural areas + interurban transport and energy infrastructure:

a) relatively higher sustainability, THS: purchase of equipment for accumulation of solar energy; construction of wind generator installations; construction of monorail roads and hinged magnetic roads for intercity transportation; investments to fixed capital of forest-plantings (including by deductions from the cost of vouchers and «green» mortgages); designing and construction of private «green» buildings, with autonomous heating blocks; construction of ecological engineering structures - load-bearing and noise-protective walls, over-crossings, roads, bridges; reconstruction of waste landfills: creation of soilfilled volumes with greening the open surfaces of soil; combining the construction of buildings and engineering structures with equipment for utilization of renewable energy, having accumulative possibilities; programs of transferring railways under the ground with reproduction of radical «green corridors» on their current places; programs of transferring highways under the ground; «trapping» of vehicle emissions, collection and utilization under the ground;

b) relatively lower sustainability, TLS: creation of facilities for production of cement and dry mixtures absorbing $\mathrm{CO}_{2}$; modernization of woodworking enterprises to produce fuel from wood waste as well as paper from soft wood varieties and hemp; preservation and restoration of eco-networks and recording migration channels in designing and construction; «ecological» traffic connections that do not prevent fauna migration; production of light-weight materials and structures (including through smaller structures and the use of less powerful lifting and transport machines); ecological projects (construction of «green» buildings for rest and treatment); designing and construction of private «green» buildings with autonomous heating blocks; development, designing and construction of energy-active buildings and engineering structures with justification of possibility to use one or more sources of renewable energy: solar, wind, geo-, hydro-thermal and bio-energy; programs of transferring highways under the ground; «trapping» of vehicle emissions, collection and utilization under the ground.

Conclusions and perspectives for further findings from this research as well as perspectives for further developments in this area. The analysis made with regard to the concept of the sector competitiveness gave opportunity to determine that at present the achievement of the success in any sector is possible by means of not the inherited factors only, but the actions of mechanisms being capable to continuously improve the efficiency of using these factors. One of these The analysis made with regard to the concept of the sector competitiveness gave opportunity to determine that at present the achievement of the success in any sector is possible by means of the inherited factors, as well as the actions of mechanisms being capable to continuously improve the efficiency of using these factors. One of these mechanisms to encourage the international competitiveness, in our opinion, can become the program of 
Ю.В. Орловська, О.О. Квактун, В.С. Чала, М.С. Вовк. Програми зелених інвестицій як елемент міжнародної конкурентоспроможності галузі (на прикладі будівництва)

green investment to the construction sector. Thus, the element of scientific novelty of the research can be deemed the following: the universal program of green investments has been developed for the first time to increase the international competitiveness of the construction sector in Ukrainian regions.

The study identified the main and most common areas to involve green investments in order to increase the international competitiveness of the construction sector, among which there are the following ones: development of ecology-oriented and energy-efficient technologies for reconstruction of housing and utilities complex and construction of new housing, as well as new innovative and ecological building; innovations in the sphere of building materials; new construction of facilities for environmentally safe energy production, including the use of renewable energy sources and secondary raw materials as well as reduction of energy consumption during transportation; capital investments in the field of waste management with regard to their involvement into economic turnover; reconstruction of existing facilities for energy generation; development of the system for forest management investment mechanisms; creation of the specific territorial system for sustainable designing and construction of buildings and structures; "sustainable» development of the underground space; healthy master layouts of cities and "green» design technologies; implementation of systems of ecological standards for designing and construction, etc. The authors separated the main effects from "green technologies» in construction and designing. Further research is required in relation to the issue of complex quantitative assessment of the international competitiveness in the sector and forecasted volumes of its green investment.

1. Андреева Н.Н. Экологически ориентированные инвестиции: выбор решений и управление: монография / Н.Н. Андреева. - Одесса: ИПРЭЭИ НАН Украины, 2006. - 536 с.

2. Андронова Н. Экологическая выгода [Электронный ресурс] / Н. Андронова. - Режим доступа: http://www. ustrazvitie.narod.ru/Russian.htm.

3. Аніщенко В.О. До питання щодо вдосконалення теоретико-методологічних засад екологічного інвестування / В.О. Аніщенко // Актуальні проблеми економіки. - 2007. - № 8. - С. 175-183.

4. Арестов С.В. Формирование и развитие понятийно-категориального апарата природоохранных инвестиций в Украине / С.В. Арестов // Наукові праці: Економіка. - 2010. - Випуск 132. - Том 145. - С. 70-74

5. АнтонюкЛ.Л. Міжнародна конкурентоспроможність країн: теорія та механізм реалізації: монографія / Л.Л. Антонюк. - К:: КНЕУ, 2004. - 275 с.

6. Благой В.В. Екологічно спрямоване інвестування / В. В. Благой // Вісник НТУ «ХПІ». Серія: Технічний прогрес і ефективність виробництва. - Х.: НТУ «ХП|». - 2013. - № 66 (1039). - С. 71-75.

7. Виноградов В.Г. Обзор национальных приоритетов России в сферах деятельности приоритетных для ГЭФ и их регионального распределения на основе объективных индикаторов [Электронный ресурс] / В.Г. Виноградов,

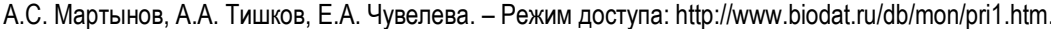

8. Вишницька О.І. Екологічні інвестиції: сутність, класифікація, принципи та напрями реалізації / О.І. Вишницька // Вісник Сумського державного університету. Серія Економіка. - 2009. - № 2. - С. 51-58.

9. Власов М.В. Инвестиции в рациональное природопользование (на примере разработки и реализации комплексных экологических программ): автореф. дис. ... канд. экон. наук: спец. 08.00.05. [Электронный ресурс] М.В. Власов. - Екатеринбург, 2004. - 32 с. - Режим доступа: http://lib.usue.ru/resource/free/avtoref/07/vlasov.pdf

10. Герасимчук 3.В. Регіональна політика сталого розвитку: методологія формування, механізм реалізації 3.В. Герасимчук. - Луцьк : Надстир'я, 2000. - 250 с.

11. Дергачова В.В. Міжнародна конкурентоспроможність національної економіки в контексті забезпечення економічного зростання: монографія / В. В. Дергачова. - Донецьк: ДонДУЕТ, 2006. - 391 с.

12. Жиров А.И. Прикладная экология: учебник для ВУЗов / А.И. Жиров, В.В. Дмитриев. - М.: Academia, 2008. -600с.

13. Калюжнова Н.Я. Конкурентоспособность регионов в условиях глобализации: монографія / Н.Я. Калюжнова. - М.: Теис, 2003. -526 c.

14. Ларіонова К.Е. Інвестиційна ефективність в екологічному будівництві [Електронний ресурс] / К.Е. Ларіонова, А.Ю. Макєєв. - Режим доступу: http://masters.donntu.edu.ua/2009/fvti/larionova/library/article4.htm.

15. Лук'яненко Д.Г., Поручник А.М. Управління міжнародною конкурентоспроможністю в умовах глобалізації економічного розвитку: монографрія: У 2т. -Т.1 / Заг. ред. Д.Г. Лук'яненко, А.М. Поручник. - К.: КНЕУ, 2006. - 816 с.

16. Минрегионстрой работает над внедрением в Украине проектов домов с минимальным энергопотреблением [Электронный ресурс]. - Режим доступа: http://www.rbc.ua/rus/all/arc/2010/01/27

17. Орловська Ю.В., Квактун О.О. Стратегічне управління екологічними інвестиціями: регіональний аспект: 
монографрія / Ю.В. Орловська, О.О. Квактун. - Дніпропетровськ: ДВНЗ «ПДАБА», 2011. - 280 с.

18. Орловська Ю.В., Квактун О.О., Вовк М.С. Екологічні інвестиції в конкурентній моделі розвитку регіонів: монографія / Ю.В. Орловська, О.О. Квактун, М.С. Вовк. - Саарбрюккен: Lap Lambert Publishing, 2012. - 217с.

19. Піддубна Л.І. Конкурентоспроможність економічних систем: теорія, механізм регулювання та управління : монографія / Л. І. Піддубна. - Х.: ІНЖЕК, 2007. - 368 с.

20. Портер М. Международная конкуренция: Конкурентные преимущества стран / Пер. с англ. И.В.Квасюка. - М.: Международные отношения, 1993. - 896 с

21. Портер М. Конкурентная стратегия: методика анализа отраслей и конкурентов / М. Портер / Пер с англ. И.Минервина. - М. : Альпина Бизнес Букс, 2005. - 454 с.

22. Публикации по устойчивому развитию журнала «Полис» [Электронный ресурс]. - Режим доступа: http://politsludics.ru/fulltext/2003/2/15.htm

23. Тарабунщиков Ю.А. Строительные концепции зданий XXI века в области теплоснабжения и климатизации [Электронный ресурс] / Ю.А. Тарабунщиков. - Режим доступа: http:// www.abok.ru/forspec/frtecles.php

24. Тетиор А.Н. Архитектурно-строительная экология. Учебное пособие / А.Н. Тетиор. - М.: Академия, 2008. - 368 с

25. Хазин В.В. Концепция экологоустойчивого производства и потребления на Украине и в Крыму [Электронный ресурс] / В.В.Хазин, А.К.Лившиц, А.И. Горовая. - Режим доступа: http://www.nbuv.gov.ua/portal/natural/uztnu/law 12008_2/028.pdf.

26. Шнипко О.С. Конкурентоспроможність України в умовах глобалізації : монографія / О.С. Шнипко. - К.: Інститут економіки та прогнозування, 2009. - 456 c.

27. BREEAM (BRE Environmental Assessment Method) [Electronic resource]. - Access mode: http://www.bre.co.uk/page.isp?id=1578.

28. Dunning J.H. Multinationals and Industrial Competitiveness: A New Agenda / J.H. Dunning, R. Narula. - London: Edward Elgar Publishing Ltd, 2004.

29. Hamel, G. Competing for the future / G. Hamel, C.K. Prahalad. Boston, MA: Harvard Business School Press, 1994.

30. Novacem is a World Economic Forum Technology Pioneer [Electronic resource]. - Access mode: http://novacem.com/

31. The Technology / Economy Programme. Technology and Economy. The Key Relationships. Paris: OECD, 1992.

32. U.S. Green Building Counsil (LEED) [Electronic resource]. - Access mode: http://www.usgbs.org/News/PressReleaseDetails.aspx?ID=289.

1. Andreeva, N.N. (2006). Jekologicheski orientirovannye investicii: vybor reshenij $i$ upravlenie [Ecologically oriented investments: decision making and management]. Odessa : IPRJeJel NAN Ukrainy [in Russian].

2. Andronova, N. (n.d.). Jekologicheskaja vygoda [Ecological benefit]. ust-razvitie.narod.ru. Retrieved from: http://www.ustrazvitie.narod.ru/Russian.htm [in Russian]

3. Anischenko, V.O. (2007). Do pytannia schodo vdoskonalennia teoretyko-metodolohichnykh zasad ekolohichnoho investuvannia [Towards theoretical and methodological aspects development concerning ecologic investments]. Aktualni problemy ekonomiky - Actual Problems of Economics, 8, 175-183 [in Ukrainian].

4. Arestov, S.V. (2010). Formirovanie i razvitie ponjatijno-kategorialnogo aparata prirodoohrannyh investicij v Ukraine [Terminological background development concerning environmentally friendly investments in Ukraine]. Naukovi pratsi: Ekonomika - Scientific workouts: Economics, issue 132 (145), $70-74$ [in Russian].

5. Antoniuk, L.L. (2004). Mizhnarodna konkurentospromozhnist krain: teoriia ta mekhanizm realizatsii [International competitiveness of countries: theory and realization mechanism]. Kyiv: KNEU [in Ukrainian].

6. Blahoj, V.V. (2013). Ekolohichno spriamovane investuvannia [Ecologically oriented investment]. Visnyk NTU «KhPI». Seriia: Tekhnichnyj prohres i efektyvnist vyrobnytstva - Scientific revue of NTU "HPI": ser. Technical progress and production effectiveness., 66 (1039), 71-75. Kharkiv: NTU «KhPI» [in Ukrainian].

7. Vinogradov, V.G., Martynov, A.S., Tishkov. A.A., \& Chuveleva E.A. Obzor nacionalnyh prioritetov Rossii v sferah dejatelnosti prioritetnyh dlja GJeF $\mathrm{i}$ ih regionalnogo raspredelenija na osnove obektivnyh indikatorov [Overview of Russian national priorities of energy efficiency fund and their regional distribution considering objective indicators]. (n.d.). biodat.ru. Retrieved from: http://www.biodat.ru/db/mon/pri1.htm [in Russian].

8. Vyshnytska, O.I. (2009). Ekolohichni investytsii: sutnist, klasyfikatsiia, pryntsypy ta napriamy realizatsii [Ecological investments: essence, classification, principles and realization directions]. Visnyk Sumskoho derzhavnoho universytetu. Seriia Ekonomika - Scientific Revue of Sumsky National University: ser. Economics ,2, $51-58$ [in Ukrainian].

9. Vlasov, M.V. (2004). Investicii v racionalnoe prirodopolzovanie (na primere razrabotki i realizacii kompleksnyh jekologicheskih programm) [Investments into rational nature use (through ecological programs development and realization)]. Extended abstract of candidate's thesis. Ekaterinburg: UGJeU. Retrieved from http://lib.usue.ru/resource/free/avtoref/07/vlasov.pdf. [in Russian]

10. Herasymchuk, Z.V. (2000). Rehionalna polityka staloho rozvytku: metodolohiia formuvannia, mekhanizm realizatsii [Regional policy for sustainable development: formation methodology, realization mechanism]. Lutsk : Nadstyria [in Ukrainian].

11. Derhachova, V.V. (2006). Mizhnarodna konkurentospromozhnist natsional noi ekonomiky $v$ konteksti zabezpechennia ekonomichnoho zrostannia [National economy's international competitiveness in line with economic growth provision]. Donetsk: 
Ю.В. Орловська, О.О. Квактун, В.С. Чала, М.С. Вовк. Програми зелених інвестицій як елемент міжнародної конкурентоспроможності галузі (на прикладі будівництва)

DonDUET [in Ukrainian]

12. Zhirov, A.I., \& Dmitriev, V.V. (2008). Prikladnaja jekologija [Applied economy]. Moskow: Academia [in Russian].

13. Kaljuzhnova, N.Ja. (2003). Konkurentosposobnost regionov $v$ uslovijah globalizacii [The competitiveness of the regions in the terms of globalization]. Moscow: Teis [in Russian ].

14. Larionova, K.E., \& Makieiev A.Yu. (2009). Investytsijna efektyvnistv ekolohichnomu budivnytstvi [Investment efficiency in ecological]. masters.donntu.edu.ua. Retrieved from: http://masters.donntu.edu.ua/2009/fut//larionova/library/article4.htm [in Ukrainian].

15. Lukianenko, D.H., \& Poruchnyk, A.M. (Eds.) (2006). Upravlinnia mizhnarodnoiu konkurentospromozhnistiu v umovakh hlobalizatsii ekonomichnoho rozvytku [Managing international competitivenss in terms of economic development globalization] (Vols 1-2). Kyiv: KNEU [in Ukrainian].

16. Minregionstroj rabotaet nad vnedreniem $v$ Ukraine proektov domov s minimalnym jenergopotrebleniem [Minestry of regional construction works on implementation of minimal energy consumption buildings]. (2010). rbc.ua. Retrieved from http://www.rbc.ua/rus/all/arc/2010/01/27 [in Russian].

17. Orlovska, Yu.V., \& Kvaktun, O.O. (2011). Stratehichne upravlinnia ekolohichnymy investytsiiamy: rehionalnyj aspekt [Strategic management of ecological investments: regional aspect] Dnipropetrovsk: DVNZ «PDABA» [in Ukrainian].

18. Orlovska, Yu.V., Kvaktun, O.O., \& Vovk, M.S. (2012). Ekolohichni investytsii v konkurentnij modeli rozvytku rehioniv [Ecological investments in competitive model of regional development] Saarbriukken: Lap Lambert Publishing [in Ukrainian].

19. Piddubna, L.I. (2007). Konkurentospromozhnist ekonomichnykh system: teoriia, mekhanizm rehuliuvannia ta upravlinnia [Economic systems competitiveness: theory, regulation mechanism and management]. Kharkiv: INZhEK [in Ukrainian].

20. Porter, M. (2005). Konkurentnaja strategija: metodika analiza otraslej $i$ konkurentov [Competitive strategy : industry and competitors' analysis]. (I. Minervin Trans.) Moscow: Alpina Biznes Buks [in Russia ].

21. Porter, M. (1993). Mezhdunarodnaja konkurencija: Konkurentnye preimushhestva stran [International competition: competitive advantages of countries]. (I.V.Kvasjuka Trans). Moscow: Mezhdunarodnye otnoshenija [in Russian].

22. Publikacii po ustojchivomu razvitiju zhurnala «Polis» (2003). [Sustainable development publications in 'Polis' Journal]. politsludics.ru. Retrieved from: http://politsludics.ru/fulltext/2003/2/15.htm [in Russian].

23. Tarabunshhikov, Ju.A. Stroitelnye koncepcii zdanij XXI veka v oblasti teplosnabzhenija i klimatizacii [Building concepts of XXI century in sphere of heating and climatization]. (n.d.). abok.ru. Retrieved from: http:// www.abok.ru/forspec/frtecles.php

24. Tetior, A.N. (2008). Arhitekturno-stroitelnaja jekologija [Architectural and building ecology]. Moskow: Akademija [in Russian].

25. Hazin, V.V., Livshic, A.K., \& Gorovaja A.I. (2008). Koncepcija jekologoustojchivogo proizvodstva i potreblenija na Ukraine i V Krymu [Ecologically sustainable production in Ukraine and Crimea]. Retrieved from http://www.nbuv.gov.ua/portal/natural/uztnu/law /2008_2/028.pdf [in Russian].

26. Shnypko, O.S. (2009). Konkurentospromozhnist Ukrainy v umovakh hlobalizatsii [Ukraine's competitiveness in terms of globalization]. Kyiv: Instytut ekonomiky ta prohnozuvannia ta prohnozuv [in Ukrainian].

27. BREEAM (BRE Environmental Assessment Method). (n.d.). bre.co.uk. Retrieved from: http://www. bre.co.uk/page. isp?id=1578.

28. Dunning, J.H., \& Narula, R. (2004). Multinationals and Industrial Competitiveness: A New Agenda. London: Edward Elgar Publishing Ltd.

29. Hamel, G., \& Prahalad, C.K. (1994). Competing for the future. Boston, MA.: Harvard Business School Press.

30. Novacem is a World Economic Forum Technology Pioneer. (n.d.). novacem.com. Retrieved from http://novacem.com/.

31. TEP. (1992). The Technology / Economy Programme. Technology and Economy. The Key Relationships. Paris: OECD.

32. U.S. Green Building Counsil (LEED). (n.d.). usgbs.org. Retrieved from: http://www.usgbs.org/News/PressReleaseDetails.aspx?ID=289.

Ю.В. Орловська, д-р екон. наук, профессор, завідуюча кафедрою міжнародної економіки, ДВНЗ «Придніпровська державна академія будівництва та архітектури» (Дніпро, Україна);

0.0. Квактун, канд. екон. наук, доцент, доцент кафедри міжнародної економіки, ДВНЗ «Придніпровська державна академія будівництва та архітектури» (Дніпро, Україна);

В.С. Чала, канд. екон. наук, доцент кафедри міжнародної економіки, ДВНЗ «Придніпровська державна академія будівництва та архітектури» (Дніпро, Україна);

М.С. Вовк, канд. екон. наук, доцент кафедри міжнародної економіки, ДВНЗ «Придніпровська державна академія будівництва та архітектури» (Дніпро, Україна)

Програми зелених інвестицій як елемент міжнародної конкурентоспроможності галузі (на прикладі будівництва)

у статті проаналізовано поняття конкурентоспроможності галузі, в результаті було визначено, що на сьогодн досягти успіху в будь-якій галузі можливо за рахунок не стільки успадкованих факторів, скільки від дії механізмів, здатних безперервно підвищувати ефрективність використання цих факторів. Автори зазначають, що однім з таких механізмів сприяння міжнародної конкурентоспроможності, може стати програма зеленого інвестування будівельної 
галузі. Таким чином, було розроблено універсальну програму зелених інвестицій задля підвищення міжнародної конкурентоспроможності будівельної галузі регіонів України. Виокремлено головні ефекти від «зелених технологій» в будівництві.

Ключові слова: будівельна галузь, міжнародна конкурентоспроможність, зелені інвестиції, «зелені» технології, «зелене» будівництво, програма заходів зелених інвестицій, рівень сталості регіону

Ю.В. Орловская, д-р экон. наук, профессор, заведующая кафедрой международной экономики, гВУЗ «Приднепровская государственная академия строительства и архитектуры» (г. Днепр, Украина);

О.А. Квактун, канд. экон. наук, доцент, доцент кафедры международной экономики, ГВУз «Приднепровская государственная академия строительства и архитектуры» (г. Днепр, Украина);

B.C. Чалая, канд. экон. наук, доцент кафедры международной экономики, гВУз «Приднепровская государственная академия строительства и архитектуры» (г. Днепр, Украина);

М.C. Вовк, канд. экон. наук, доцент кафедры международной экономики, ГВУз «Приднепровская государственная академия строительства и архитектуры» (г. Днепр, Украина)

Программы зеленых инвестиций как элемент международной конкурентоспособности отрасли (на примере строительства)

В статье проанализировано понятие конкурентоспособности отрасли, в результате чего было определено, что на сегодня добиться успеха в любой отрасли возможно не столько за счет унаследованных фракторов, сколько от действия механизмов, способных непрерывно повышать эффективность использования этих факторов. Авторы отмечают, что одним из таких механизмов повышения международной конкурентоспособности, может стать программа зеленого инвестирования строительной отрасли. Таким образом, была разработана универсальная программа зеленых инвестиций для повышения международной конкурентоспособности строительной отрасли регионов Украины. Выделены главные эффректы от «зеленых технологий» в строительстве.

Ключевые слова: строительная отрасль, международная конкурентоспособность, зеленые инвестиции, «зеленые» технологии, «зеленое» строительство, программа мероприятий зеленых инвестиций, уровень устойчивости региона

Отримано 27.01.2017 p. 